\title{
PENGEMBANGAN FITRAH MANUSIA MELALUI KONSELING ISLAM
}

\author{
Risdawati Siregar \\ Lecturer of Da'wa and Communication Sciences Faculty at IAIN Padangsidimpuan \\ Jl. T. Rijal Nurdin Km.4,5 Sihitang Padangsidimpuan 22733 \\ Email:_risdawatisiregar@gmail.com
}

\begin{abstract}
Abstrak
Fitrah is basic ability of growth and development of human who has born. There is fitrah in humans's body who has not growth and get function, so Allah closes their hearth until they can not see the truth, then they misguided and do not want to accept Allah's direction. But there is fitrah can grouth and get function, Allah gives every body physical, spiritual and nafs, therefore Allah keeps hearth and greeting full of faith and makes them as human kaffah, then they can give benefit to their environment. So, the role of guidance and Islam counseling services help everybody to develop human's fitrah, empowering faith, mind and desire for learning the demand of Allah and His Messenger.
\end{abstract}

Keywords: Fitrah dan Konseling

\begin{abstract}
Abstrak
Fitrah adalah kemampuan dasar dari pertumbuhan dan perkembangan manusia yang telah lahir. Terdapat fitrah dalam tubuh manusia yang belum tumbuh dan berfungsi, sehingga Allah menutup kediaman mereka sampai mereka tidak bisa melihat kebenaran, maka mereka sesat dan tidak mau menerima arahan Allah. Tapi ada fitrah bisa tumbuh dan berfungsi, Allah memberikan setiap tubuh fisik, spiritual dan nafsu, karena itu Allah membuat kediaman dan salam penuh iman dan membuat mereka sebagai manusia kaffah, maka mereka dapat memberikan manfaat bagi lingkungan mereka. Jadi, peran bimbingan dan Islam layanan konseling membantu semua orang untuk mengembangkan fitrah manusia, pemberdayaan iman, pikiran dan keinginan untuk belajar kebutuhan dari Allah dan Rasul-Nya.
\end{abstract}

Kata Kunci: Fitrah and Counseling

\section{PENDAHULUAN}

Semua fitrah manusia pada dasarnya sepanjang jaman, baik anak-anak dari orang beriman maupun orang musyrik dilahirkan lengkap dengan fitrah iman yaitu mengakui keesaan Allah dan tunduk kepada-Nya. Fitrah iman inilah yang melahirkan kecendrungan pada manusia pada hal-hal yang baik. Fitrah adalah kemampuan dasar pertumbuhan dan perkembangan manusia yang dibawa sejak lahir. Menurut Al-Ghazali bahwa seorang anak mempunyai fitrah kecenderungan kearah baik dan buruk. Oleh karena itu peran orangtua dan guru serta konselor sangat diperlukan untuk mengarahkannya pada perilaku baik. Dengan demikian, peran orang tua sangat besar terhadap pengembangan fitrah tersebut, 
karena orang tua merupakan pendidik pertama dan utama dalam lingkungan keluarga, demikian halnya dengan guru serta konselor memiliki peranan penting dalam mengarahkan fitrah individu kearah yang baik. Salah satu tujuan konseling dalam mengembangkan fitrah manusia adalah dengan menumbuhkembangkan fitrahnya menuju kearah pembentukan manusia sempurna, dan menjadi hamba Allah SWT yang baik, karena tujuan konseling Islam secara umum adalah membentuk manusia yang paripurna dan selalu mendekatkan diri kepada Allah SWT agar menjadi hamba yang bertaqwa. Pertanyaannya adalah kenapa ada individu yang fitrahnya tidak berkembang kemudian perilakunya tidak sesuai dengan tuntunan agama (fasik, musyrik dan tidak patuh) kepada Allah.

Selanjutnya kenapa ada individu yang fitrahnya berkembang dengan baik kemudian menjadi hamba yang beriman dan taat pada aturan Allah. Selanjutnya apa yang bisa dilakukan individu dalam mengembangkan fitrah yang dikaruniakan Allah kepadanya agar fitrah jasmani, rohani dan nafsnya berkembang optimal dan sesuai tuntunan Allah.

\section{PEMBAHASAN}

\section{PENGERTIAN FITRAH MANUSIA}

Dalam pengertian yang sederhana istilah fitrah sering dimaknai suci secara etimologis, asal kata fitrah / fitroh / pitrah berasal dari bahasa Arab, yaitu fitrah jamaknya fithar, yang suka diartikan perangai, tabiat, kejadian, asli, agama, dan ciptaan. Menurut Quraish Shihab, istilah fitrah diambil dari kata al-fithr yang berarti belahan. Dari makna ini lahir makna-makna lain, antara lain pencipta atau kejadian.

Dalam gramatika bahasa Arab, sumber kata fitrah wazannya fi'lah, yang artinya alibtida' yaitu menciptakan sesuatu tanpa contoh. Fi'lah dan fitrah adalah bentuk masdar (infinitive) yang menunjukkan arti keaadaan. Demikian pula menurut Ibn al-Qayyim dan Ibnu katsir karena fitir artinya menciptakan, maka fitrah berarti keadaan yang dihasilkan dari penciptaan itu. Menurut hadis yang diriwayatkan oleh Ibnu 'Abbas, fitrah adalah awal mula penciptaan manusia. Sebab lafadz fitrah tidak pernah dikemukakan oleh Al-Quran dalam konteksnya selain dengan manusia.

Fitrah manusia berbeda dengan watak atau tabi'at, juga berbeda dengan naluri/ garizah. Watak atau tabi'at adalah sifat dasar, seperti kalimat watak oksigen adalah mudah terbakar. Jadi watak adalah karakteristik yang terdiri daripada bentuk dan materi (maddah). Inilah yang merupakan watak atau tabi'at suatu benda. Sedangkan naluri atau garizah adalah sifat dasar. Sifat dasar ini bukan muktasabah (bukan diperoleh). Misalnya, anak kuda begitu lahir langsung bisa berdiri; semut, meskipun binatang kecil namun mampu mengumpulkan makanan. Inilah yang disebut naluri atau garizah. Dalam naluri tidak terdapat kesadaran yang penuh. Untuk binatang, fitrah ini disebut naluri. Fitrah sama dengan watak (tabi'at) dan naluri ini juga bukan diperoleh melalui usaha (muktasabah), 
bukan pula karena khuduri (perolehan). Istilah fitrah lazimnya untuk manusia, naluri lazimnya untuk hewan, dan watak lazimnya untuk benda.

Dalam Al-Quran kata fitrah disebutkan sebanyak 20 kali, terdapat dalam 17 surat dan dalam 19 ayat, muncul dengan berbagai bentuknya. Ada dalam bentuk fi'il madhi, fi'il mudharik, isim fa'il, isim maf'ul dan isim mashdar. Dalam bentuk fi'il madi sebanyak 9 kali, dimana fitrah berarti menciptakan, isim fa'il sebanyak 6 kali yang berarti menciptakan, yang menjadikan. Dalam bentuk isim maf'ul berarti menjadikan. Kemudian dalam bentuk fi'il mudari' sebanyak 2 kali, yang berarti pecah, terbelah. Dalam bentuk sebanyak 1 kali yang berarti pecah, terbelah. Dan dalam bentuk isim masdar sebanyak 2 kali yang berarti tidak seimbang.

Dari 20 kali penyebutan kata fitrah ini hanya satu ayat yang menunjukkan bentuk fitrah secara jelas, yaitu dalam surat Al-Rum ayat 30. Kata fitrah dalam ayat ini mempunyai beberapa arti. Dalam kamus Al-Munawwir, kata fitrah diartikan dengan naluri (pembawaan). Kemudian Mahmud Yunus mengatakan, kata fitrah diartikan sebagai agama, ciptaan, perangai, kejadian asli. ${ }^{1}$ Dalam kamus bahasa Indonesia (KBBI) kata fitrah diartikan dengan sifat asli, bakat, pembawaan perasaan keagamaan.

Selain itu, Lusi Makluf mengatakan, kata fitrah diartikan dengan agama, sunnah, kejadian, tabiat. Kamus Indonesia-Inggris susunan John Echols dan Hasan Sadili, mengartikan fitrah dengan natural, tendency, disposition, character. ${ }^{2}$ Dan kamus Arab-melayu mengartikan fitrah dengan agama, sunnah, mengadakan, perangai, semula jadi, kejadian (khilqatun).

Berdasarkan beberapa pengertian tentang konsep fitrah sebagaimana tersebut diatas, maka secara umum makna fitrah bermacam-macam, diantaranya adalah: fitrah dalam arti kejadian awal, bentuk awal, kemampuan dasar, potensi dasar, suci, agama, ciptaan, dan perangai. Fitrah hanya diperuntukkan bagi manusia. Sedang bagi binatang, fitrah sama dengan naluri atau tabi' at.

\section{Fitrah Manusia yang Tidak Berkembang dan Tidak Berfungsi}

Apabila fitrah iman tidak berfungsi dan berkembang dapat dikatakan kafir. Hamka Menjelaskan kafir adalah orang yang menutupi, menyelimuti, menyembunyikan sehingga tidak kelihatan lagi. Dikatakan menutupi, karena benih iman itu telah ada sejak manusia telah berada di tulang sulbi orangtua mereka, tetapi tertutup, namun hati mereka sebenarnya tahu bahwa itu kebenaran dari Allah. Ada beberapa macam kekafiran yaitu:

1. Kafir Inad yaitu kafirnya orang yang keras kepala; kebenaran yang sebenarnya telah sampai kepadanya tapi hati mereka tetap menolaknya, pelaku kafir inad bisa dilihat pada orang-orang atheis dan komunis.

\footnotetext{
${ }^{1}$ Murthada Muthaharri, Fitrah Cetakan I (Jakarta: Paramadina,1989), Hlm. 6

2 Jhon. M. Echols dan hasan Shadily, Kamus Indonesia-Inggris, (Jakarta Gramedia, 1994), Hlm.164
} 
2. Kafir Juhud yaitu kafirnya orang yang kebenaran sebenarnya telah sampai kepadanya, tetapi karena dirasa menggganggu kedudukan atau jabatannya maka ditolaklah kebenaran itu.

3. Kufur nikmat, mungkin orang itu mukmin, tetapi ia selalu mengeluh terus karena kesusahan, padahal nikmat Allah tetap diterima, ia lupakan nikmat karena kesusahan.

4. Kafirnya orang tahu kebenaran, tetapi ia tidak mau mengakuinya.

5. Orang yang buta agama yaitu orang yang tidak ada perhatian sama sekali kepada agama, yang penting uang di dapat dan perut diisi. Ini adalah kafir karena bodoh yang masih mungkin diperbaiki dengan bimbingan agama. ${ }^{3}$

Orang kafir yang menolak kebenaran yang datang dari Allah, akhirnya Allah mengunci hati dan pendengaran mereka, yakni Allah membiarkan mereka larut dalam kesesatan sesuai keinginan hati mereka sendiri akhirnya hati dan telinga mereka tidak bisa menerima bimbingan. Mata mereka pun tertutup sehingga mereka tidak mampu melihat kebenaran yang terhampar di jagad raya ini, kecuali sekedar fenomenanya. Orang-orang inilah yang termasuk dalam kelompok orang kafir dan munafik, sebab orang munafik yang hatinya juga menolak kebenaran yang datang dari Allah. Orang kafir dan orang munafik ada dalam kesesatan, akibat kesesatan itu ia enggan menerima petunjuk Allah, sehingga kesesatan mereka semakin jauh.

Iman yang tidak berfungsi dimaksudkan sebagai gambaran individu lahiriyah telah memeluk agama Islam, ia juga mengetahui sejumlah perintah dan larangan dalam agama, tetapi hatinya tidak tergerak untuk mematuhinya. Seseorang tahu agama memerintahkan untuk beribadah tetapi ia tidak melaksanakannya atau ia melaksanakan ibadah akan tetapi tidak sesuai dengan tuntunan-Nya, akibat ia tidak mendapatkan dan tidak merasakan lezatnya buah iman atau hikmah yang tersedia dibalik pelaksanaan ibadah. ${ }^{4}$

Individu mengaku telah beriman, tetapi perilakunya dalam kehidupan sehari-hari tidak baik, padahal manusia pembawaaanya cenderung kepada hal-hal yang positif lantaran fitrah iman. Kondisi seperti ini disebabkan karena fitrah iman yang ada pada diri individu tidak bisa berkembang dengan sempurna atau imannya berkembang tetapi tidak berfungsi dengan baik. Sebab iman yang berkembang dengan sempurna tentu mampu berfungsi sebagai pemberi arah, pendorong dan sekaligus pengendali bagi fitrah jasmani, rohani dan nafs yang pada akhirnya akan melahirkan kecendrungan untuk berprilaku yang positif.

Rasulullah menjelaskan bahwa pembawaan anak sejak lahir cendrung bersumber dari fitrah berupa iman yang telah dikaruniakan Allah kepada setiap manusia sejak masih dalam rahim. Iman membutuhkan perawatan adalah dengan cara mendidik dan

3 M. Q. Shihab, Wawasan Al-Quran. Tafsir Maudhu'I Atas Pelbagai Persoalan Umat,Juz I-XV, (Bandung:Mizan, 2002), Hlm. 95

${ }^{4}$ Hamka, Tafsir Al-Azhar,Juz I-XXX, (Jakarta: Pustaka Panjimas,1984), Hlm.159 
melaksanakan ibadah sesuai tuntunan Allah. Kelakuan anak yang salah bisa saja datang dari kelalaian orangtua dalam mendidiknya. Kelalaian itu bisa berbentuk:

1. Tidak memberikan pendidikan agama pada anak yang mengakibatkan ajaran agama tidak sampai kepadanya;

2. Orang tua tidak memberikan dukungan financial dan keteladanan yang mengakibatkan anak tidak bisa mengamalkan ajaran agama beribadah secara baik dan benar; padahal melaksanakan ajaran agama adalah sebagai pupuk yang menyuburkan fitrah iman;

3. Orangtua tidak menanamkan kebiasaan kepada anak untuk mempelajari dan mengamalkan ajaran agama sejak dini atau pihak lain yang menghendaki iman anak tidak tumbuh subur;

4. Ada kesenjangan orangtua sendiri dan pihak lain yang menghendaki iman individu lemah, mudah digelincirkan setan dan menjadi pribadi yang tidak utuh (fasik, munafik atau kafir). ${ }^{5}$

\section{Fitrah Iman yang Berkembang dan Berfungsi.}

Fitrah iman yang berkembang dengan baik kemudian menjadi hamba yang beriman dan taat pada aturan Allah, bisa ditelusuri melalui ayat-ayat Al-Qur'an dan hadist tentang bagaimana profil pribadi individu yang fitrahnya dengan baik dan faktor apa sebenarnya yang menyebabkan individu bisa berkembang sehingga menjadi pribadi yang kaffah. Esensi fitrah manusia mengakui keesaan Allah dan taat kepada Allah, seperti yang terdapat dalam al-Qur'an yang artinya: Dan (ingatlah), ketika Tuhanmu mengeluarkan keturunan anakanak Adam dari sulbi mereka dan Allah mengambil kesaksian terhadap jiwa mereka (seraya berfirman): "Bukankah aku ini Tuhanmu?" mereka menjawab: "Betul (Engkau Tuban kami), Kami menjadi saksi". (kami lakukan yang demikian itu) agar di hari kiamat kamu tidak mengatakan: "Sesungguhnya Kami (Bani Adam) adalah orang-orang yang lengah terhadap ini (keesaan Tuhan)".

Dari esensi fitrah nampak bahwa fitrah manusia tercakup dalam Islam dan ikhsan artinya fitrah manusia sejak lahir bukan hanya menyakini bahwa Allah adalah Maha Esa, tetapi lebih dari itu kesediaan diri untuk melaksanakan apa yang diperintahkan Allah dan menjauhi segala larangannya. Bahwa Allah telah membekali pada setiap individu dengan fitrah jasmani, fitrah rohani dan fitrah nafs serta potensi alam untuk manusia. Disamping itu juga diutusnya para rasul dengan membawa kitab suci sebagai pedoman. Pertanyaan yang muncul jika esensi fitrah manusia adalah iman kepada Allah dan tunduk kepadanya. Menurut Sayyid Qutub bahwa keimanan mengandung beban amanah yang memiliki konsekuensi jihad yang memerlukan kesabaran dan usaha yang memerlukan daya tahan 
kerana tidak cukup seseorang mengatakan" saya beriman kemudian mereka membiarkan begitu saja, mereka di coba dan diuji oleh Allah. ${ }^{6}$

Allah memberi ujian kepada orang-orang beriman bukan tanpa tujuan, tetapi tujuannya adalah untuk mengetahui siapa-siapa yang sungguh-sungguh dan siapa yang sabar, siapa yang beriman dan siapa yang berdusta. Allah memberi ujian dengan tujuan untuk mempersiapkan manusia memikul amanat untuk membimbing manusia menuju jalan Allah serta menegakkan kalimat-Nya di pentas hidup ini. Perintah Allah orang mukmin berupaya agar menjadi orang mukmin yang sungguh-sungguh (kaffah) tertera dalam surat Al-Baqaroh ayat 208 yang berbunyi:

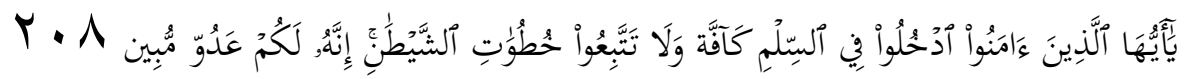

Artinya: Hai orang-orang yang beriman, masuklah kamu ke dalam Islam keseluruhan, dan janganlah kamu turut langkah-langkah syaitan. Sesungguhnya syaitan itu musuh yang nyata bagimu.

M. Quraish Shihab mengagambarkan orang yang fitrahnya berkembang dengan baik berdasarkan dalam surat Ibrahim Ayat 24-26 yang berbunyi:

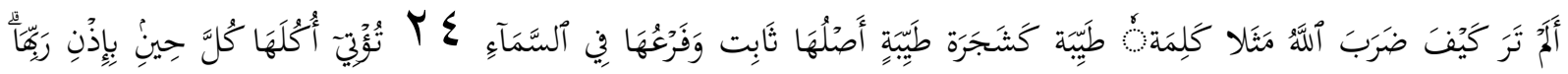

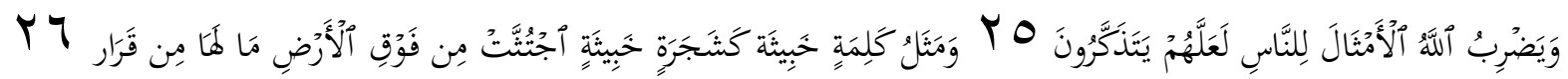

Artinya: Tidakkah kamu perhatikan bagaimana Allah telah membuat perumpamaan kalimat yang baik seperti pohon yang baik, akarnya teguh dan cabangnya (menjulang) ke langit, pohon itu memberikan buahnya pada setiap musim dengan seizin Tuhannya. Allah membuat perumpamaan-perumpamaan itu untuk manusia supaya mereka selalu ingat. Perumpamaan kalimat yang buruk seperti pohon yang buruk, yang telah dicabut dengan akar-akarnya dari permukaan bumi; tidak dapat tetap (tegak) sedikitpun.

Setiap saat individu memberi mamfaat kepada lingkungan sekitarnya dengan izin Allah. Fitrah yang berkembang digambarkan sebagai pohon yang baik yaitu pohon yang memberikan buahnya pada saat setiap musim dengan seizin allah yaitu pohon kurma. Pohon kurma digambarkan oleh Allah sebagai pohon yang baik digambarkan sebagai pribadi orang muslim. ${ }^{7}$

Manusia yang fitrahnya berkembang Allah akan meneguhkan orang -orang beriman dengan ucapan yang teguh di dunia dan akhirat dan keimanan mereka akan menjadi semakin mantap dan menjadi manusia yang kaffah. Menurut Usman Najati menggambarkan pribadi yang kaffah yaitu:

'Sayyid Qutub, Tafsir Fi Zilalil Qur'an: Dibawah Naungan Al-Qur'an. Juz I-XI, ( Jakarta: Gema Insani,2000), Hlm. 84

${ }^{7}$ Quraish Shihab, Wawasan Al-Quran....2002, Hlm 53 
1. Dalam hal aqidah ia meyakini sepenuhnya kepada Allah, para Rasul-Nya, kitabkitab-Nya, malaikat-Nya, hari akhir, kebangkitan dan perhitungan, surga dan neraka, hal yang ghaib dan qadar.

2. Berkenaan dengan ibadah, ia hanya beribadah kepada Allah dan tidak kepada selainNya, mendirikan sholat, berpuasa, membayar zakat, melaksakan haji, berjihad dijalan Allah dengan jiwa dan harta dan serta selaluingat kepada Allah.

3. Dalam hubungan sosial, ia bergaul dengan orang lain secara baik, dermawan dan suka berbuat kebajikan, suka bekerjasama, tidak memisahkan diri dari jamaah, menyeru kepada kebaikan dan mencegah dari kemungkaran, suka memanfaatkan, mendahulukan kepentingan orang lain dan menghindari diri dari hal-hal yang tidak ada mamfaatnya.

4. Dalam hubungan kekeluargaan, ia berbuat baik kepada orangtua dan kerabat, bergaul secara baik antara suami istri menjaga dan membiayai keluarga dengan rizki yang halal.

5. Sifat-sifat moral: ia sabar, lapang dada, lurus adil melaksanakan amanat, menepati janji kepada Allah, menjauhi dosa, merendahkan diri, teguh dalam kebenaran di jalan allah, mempunyai kehendak yang kuat dan mampu mengendalikan hawa nafsu.

6. Sifat-sifat emosional: ia takut kepada allah, takut akan azab Allah, tidak putus asa akan rahmat Allah, cinta dan senang berbuat kebajikan kepada sesama, menahan marah dan bisa mengendalikan kemarahan, tidak suka memusuhi orang lain dan menyakitinya, tidak dengki pada orang lain, tidak menyombongkan diri, penyayang, dan menyesali diri setelah melakukan dosa.

7. Sifat intelektual dan kognitif yaitu ia memikirkan alam semesta selalu menuntut ilmu, tidak mengikuti sesuatu yang masih merupakan dugaan, teliti dalam meneliti suatu realitas dalam berfikir dan beraqidah.

8. Sifat-sifat yang berkenaan dengan kehidupan praktis dan professional: ia tulus dalam bekerja dan menyempurnakan pekerjaan, berusaha dengan giat dalam upaya memperoleh rizki

9. Sifat-sifat fisik: ia kuat, sehat, bersih dan suci dari najis. ${ }^{8}$

Diakui Sifat-sifat seorang mukmin seperti disajikan diatas tidaklah terlepas antara satu dengan yang lainnya, tetapi saling berinteraksi dan saling menyempurnakan. Oleh karena itu tingkah laku seorang mukmin nampak serasi, baik dalam hubungannya dengan Allah, dengan orang lain atau dengan diri sendiri. Namun diakui sifat-sifat yang berhubungan dengan aqidah dipandang sangat penting dan berperan utama dalam mengarahkan seksaligus mengendalikan tingkah laku individu dalam seluruh bidang kehidupan.

${ }^{8}$ Anwar Sutoyo, Bimbingan dan Konseling...2009, Hlm. 128 


\section{Pengembangan Fitrah Manusia Melalui Konseling.}

Sebagai "hamba Allah SWT" manusia harus tunduk dan patuh kepada-Nya, ada perintah yang harus dilakukan dan larangan yang harus dijauhi, serta ada peraturanperaturan yang harus ditaati. Dalam belajar memahami diri dan memahami aturan Allah SWT ini tidak jarang terjadi "kegagalan", oleh sebab itu mereka membutuhkan bantuan khusus, baik dalam bentuk bimbingan atau konseling, inilah yang menjadi hakekat dari bimbingan dan konseling Islami. Bimbingan dan konseling Islami sebagai upaya membantu individu belajar mengembangkan fitrah (potensi) manusia dan atau kembali kepada fitrah dengan cara memberdayakan (enpowering) iman, akal, dan kemauan yang dikaruniakan Allah SWT kepadanya untuk mempelajari tuntunan Allah dan Rasul-Nya, agar fitrah yang ada pada individu dapat berkembang dengan benar dan kokoh sesuai tuntunan-Nya. Oleh karena itu, referensi utama yang dijadikan sebagai rujukan dalam bimbingan dan konseling Islami adalah "tuntunan Allah SWT", yaitu Al-Qur'an dan Sunnah Rasul. Maka menusia patuh dan taaat kepada aturan yang ada dalam Al-qur'an dan Hadits.

Peran utama konselor dalam bimbingan dan konseling Islami adalah sebagai "Pengingat", sebagai orang yang mengingatkan individu yang dibimbing dengan ajaran agama Islam. Pada dasarnya individu sudah dibekali Allah dengan fitrah iman, jika iman tidak tumbuh, diduga individu tersebut lupa merawatnya, lupa memberi pupuk, atau diserang penyakit, sehingga iman tidak dapat tumbuh dan tidak berfungsi dengan baik. Allah telah mengutus Rasul-Nya dengan Al-Qu'ran sebagai pedoman hidup yang sempurna, jika ada individu yang "kebingungan" dan "salah jalan" dalam menjalani kehidupannya, diduga individu tersebut belum memahami petunjuk yang terdapat dalam Al-Qur'an dan Sunnah Rasul sebagai implementasi Al-Qur'an dalam kehidupan sehari-hari. Disinilah peran muslim yang mempunyai keahlian sebagai konselor untuk mengingatkannya.

Prinsip dasar bimbingan dan konseling Islami adalah prinsip-prinsip yang terkandung dalam ajaran agama Islam, dalam Al-Quran dan Sunnah Rasul, yang dijabarkan sebagai berikut: Islam mengajarkan pengikutnya untuk memberikan nasihat dan saling membantu dalam kebaikan dan ketakwaan. Ini berarti bahwa setiap kegiatan membantu individu yang mengacu pada hukum-hukum Allah memiliki nilai Ibadah. Manusia ada di bumi bukan atas kehendaknya sendiri melainkan diciptakan Allah. Ada Sunnatullah (hukum dan peraturan Allah) yang berlaku untuk semua manusia, selamanya. Oleh karena itu, setiap manusia harus menerima dan patuh pada Sunnatullah.

- Allah menciptakan manusia dengan maksud dan tujuan. Allah menciptakan manusia sebagai hamba sekaligus khalifah-Nya di bumi. Sebagai hamba, manusia harus selalu beribadah kepada-Nya. Dan, sebagai khalifah, manusia mengemban tanggung jawab dibidangnya masing-masing, yang akan dipertanggungjawabkan dihadapan Allah. 
Untuk itu, dalam setiap kegiatan pelayanan bimbingan dan konseling Islami harus sesuai Sunnatullah dan dilandasi sebagai ibadah, mencari ridha Allah.

- Manusia dilengkapi dengan fitrah iman sebagai navigator dan kontrol bagi fitrah yang lain (tubuh, jiwa, dan nafsu). Oleh karena itu, dalam bimbingan dan konseling Islami harus fokus pada menjaga, memelihara, dan menumbuhkan iman dalam bentuk pemahaman individu terhadap Al-Quran dan Sunnah Rasul, serta pengamalannya dalam kehidupan sehari-hari.

- Allah memberikan kebebasan pada manusia untuk memenuhi fitrahnya. Namun, pemenuhannya diatur dengan hukum Allah. Bimbingan dan konseling Islami harus ditujukan untuk memungkinkan individu secara bertahap membimbing diri mereka sendiri dalam memenuhi kebutuhan fitrahnya sesuai dengan hukum Allah.

- Bimbingan dan konseling Islami terbuka pada hasil penelitian dan pengembangan ilmu pengetahuan sepanjang tidak bertentangan dengan ajaran agama Islam. ${ }^{9}$

Hal terpenting yang harus dipahami oleh konselor maupun klain adalah, bahwa dalam bimbingan dan konseling Islami tugas konselor hanyalah membantu, klien sendirilah yang harus berupaya untuk hidup sesuai dengan tuntunan Islam. Oleh karena itu tahaptahap bimbingan dan konseling Islami adalah:

1. Meyakinkan individu akan keberadaannya sebagai makhluk ciptaan Allah, keimanan yang benar sangat penting bagi keselamatan hidupnya di dunia dan akhirat. Ada hikmah dibalik musibah, ibadah, dan syariah yang ditetapkan Allah untuk manusia.

2. Mendorong dan membantu individu memahami dan mengamalkan ajaran Islam secara benar, sebagai jalan hidup. Untuk itu, individu perlu mengatur waktu dan energi untuk mempelajari agama Islam secara teratur dengan memanfaatkan berbagai sumber daya dan media.

3. Mendorong dan membantu individu memahami dan mengamalkan iman, islam, dan ihsan dengan benar dan konsisten dalam bentuk aktualisasi pilar iman, rukun Islam, dan ihsan dalam kehidupan sehari-hari.

Dalam bimbingan konseling pengembagan fitrah yang dapat dilakukan individu untuk berkembang secara optimal sesuai tuntunan Allah dipandang perlu karena manusia diciptakan oleh Allah sesuai dengna essensi fitrah manusia. Pada dasarnya semua manusia tujuan utama diciptakan-Nya sebagai khalifah di muka bumi dan sekaligus beribadah kepada-Nya. Ibadah yang dilakukan oleh manusia pada dasarnya bukan untuk Allah tetapi untuk manusia itu sendiril; artinya, manfaat atau hikmah melaksanakan ibadah kepada Allah tujuan allah untuk mengetahui ciptaan-Nya termasuk di dalamnya kecenderungan, kekuatan dan kelemahannya. Oleh sebab itu sejak masih dalam tulang sulbi orangtuanya, Tuhan telah mengambil janji dengan manusia bahwa Allah adalah Tuhan-Nya, isi perjanjian

${ }^{9}$ Zakia Drajat, Psikoterafi Islam, (Jakarta Bulan Bintang, 2002) Hlm 45. 
itu adalah manusia mengakui bahwa Allah adalah Tuhannya dan manusia tunduk kepadaNya.

Pengakuan manusia bahwa Allah adalah Tuhan-Nya inilah yang dipahami oleh para Mufassir sebagai fitrah atau fitrahliddiin. Jika ada orang yang tidak mengakui atau mengingkari adanya Allah maka orang itu disebut orang yang telah mengingkari fitrahnya sendiri, dan pengingkaran itu hanya bersifat sementara sebab ketika ia tidak berdaya seperti kasus Fir'aun akhirnya ia juga kembali kepada fitrahnya. Segala bentuk pengingkaran manusia terhadap Tuhan dan ketaatan kepada-Nya dibelakangnya ada Iblis sebagai fihak yang selalu berupaya menjerumuskan manusia dan akibat dari pengingkaran terhadap syariat Allah menyebabkan fitrah individu tidak berkembang secara optimal.

Dari pemahaman nampak, bahwa kunci utama untuk memelihara dan mengembangkan fitrah manusia terletak pada tingkat pemahaman individu terhadap kitab suci agamanya dan kesiapan untuk menataatinya. Dengan kata lain individu harus memahami dan mentaati apa yang diajarkan Allah dalam kitab suci-Nya. Kegiatan utama yang harus dilakukan untuk membantu mengembangkan fitrah manusia adalah mendorong dan membantu individu memahami ajaran agamanya. Dengan memahamai syariat agama secara benar diharapkan fitrah iman yang ada pada diri individu bisa berkembang secara optimal dan pada akhirnya dengan matangnya fitrah iman bisa berfungsi sebagai pendorong, pemberi arah dan sekaligus pengendali bagi tiga fitrah yang lain. ${ }^{10}$

Selanjutnya dalam pelaksanaan pengembangan fitrah manusia ada beberapa layanan dalam bimbingan konseling Islam yang dapat dilakukan antara lain:

1). Layanan Orientasi Agama;

Layanan yang memungkinkan umat mengenal dan memahami lingkungan keberagamaannya dari orang-orang yang dapat memberikan pengaruh agama untuk mempermudah orang berperan dilingkungan hidup keberagamaan yang baru dimasukinya. Misalnya orang yang akan masuk Islam. Sebelum mengucapkan dua kalimat syahadat, adalah sangat hikmat dan bijaksana, kalau diperkenalkan lebih dahulu makna dan hakikatnya dua kalimat syahadat yang diucapkan itu. Dengan cara demikian diharapkan orang terjauh dari sifat keterpaksaan dalam menganut agama, dengan demikian orang mudah menyesuaikan diri dengan lingkungan keberagamaannya. Dan menjadikan agama sebagai kebutuhan jiwa dan sumber kebahagiaan hidup. Disamping materi akidah yang dapat di angkat melalui orientasi agama, materi ibadah, akhlak dan muamalah bisa pula di angkat.

2). Layanan Informasi Agama.

Jenis layanan yang memungkinkan umat atau orang yang beragama menerima dan memahami informasi keberagamaannya dari sumber yang layak dipercaya untuk dapat

${ }^{10}$ M.Quraish Shihab. Wawasan....2002 Hlm.53 
digunakan sebagai bahan pertimbangan dalam melakukan amal-amal keagamaan dalam mengambil keputusan dan pertimbangan bagi penentuan sikap dan tingkah laku keberagamaan. Layanan informasi agama bertujuan membekali umat dengan berbagai hal yang sangat berguna bagi kehidupan ini.

3). Layanan Penempatan dan Penyaluran Bakat Keberagamaan.

Layanan yang memungkinkan umat beragama memperoleh penempatan dan penyaluran yang tepat dan benar dalam pengembangan hidup keberagamaan sesuai dengan potensi, minat, bakat, situasi, dan kondisi pribadi manusia beragama yang bersangkutan.

4) Layanan Bimbingan Pembelajaran/Pengajian Agama.

Layanan yang memungkinkan orang beragama mengembangkan sikap dan kebiasaan belajar agama yang baik, materi pengajian agama yang cocok dengan kecepatan dan kesulitan belajar agama, serta berbagai aspek tujuan dan kegiatan belajar agama lainnya yang berguna bagi kehidupan keberagamaan.

5) Layanan Konseling Agama Perorangan.

Layanan yang memungkinkan orang beragama mendapatkan layanan langsung tatap muka dengan konselor agama dalam rangka dapat dilayani melalui konseling agama perorangan ini meliputi semua aspek keagamaan. Konselor agama melayani klien secara individual.

6) Layanan Bimbingan Agama Kelompok/.

Layanan yang memungkinkan sejumlah (sekelompok) orang yang beragama memperoleh kesempatan bagi pembahasan dan pengentasan masalah keberagamaan yang mereka alami masing-masing melalui suasana dan dinamika kelompok

7) Layanan Konseling Agama Kelompok.

Layanan yang dimaksudkan untuk memungkinkan sejumlah orang yang beragama secara berjamaah memperoleh bahan dan informasi dari nara sumber tertentu tentang masalah hidup keberagamaan mereka yang dapat dijadikan bahan pertimbangan dalam menentukan sikap dan tingkah laku keberagamaan. ${ }^{11}$

Adapun dalam pelayanan bimbingan konseling Islam untuk mengembangkan fitrah manusia, ada beberapa hal yang dilakukan orangtua atau pendidik adalah :

1. Fitrah berupa iman pada setiap individu seyoginya telah dipelihara dan dipupuk sejak dini, bahkan jika mungkin sejak memilih calon suami istri seharusnya individu harus dibiasakan mengamalkan apa yang diimaninya dalam kehidupan sehari-hari secara benar dan istiqomah.

2. Iman membutuhkan perawatan agar tumbuh subur, bibit iman bisa mati sebelum berkembang, atau merana karena kurang pupuk atau ditanam pula tanaman lain di

${ }^{11}$ Andi Mapiare.AT. Pengantar Konseling dan Psikoterafi, (Jakarta : PT Raja Grafindo Persada,2002) Hlm.15 
sampingnya, akibat pohon yang asli menjadi mati karena sari tanah yang harusnya dihisap tanaman yang asli dihisap pula tanaman di sekelilingnya. Oleh sebab itu dalam menanamkan keyakinan kepa anak seyoginya dijauhkan dari segala penyakit (perbuatan maksiat dan syirik) yang bisa merusak iman.

3. Mengembangkan fitrah manusia pada dasarnya adalah mengembangkan iman dan taqwa kepada Allah. Oleh sebab itu dalam bimbingan individu seyogianya dibiasakan menjadikan agama sebagai rujukan dalam setiap langkahnya dalam bentuk amal shaleh.

4. Agar setiap langkah individu bisa lebih sesuai dengan tuntunan agama maka setiap individu perlu dididik hingga mampu memahami ajaran agama secara benar dan utuh melalui Alquran dan $\mathrm{Al}$ hadist. ${ }^{12}$

\section{PENUTUP}

Potensi fitrah manusia yang diciptakan dan diberikan oleh Allah, merupakan modal kemanusiaan yang sangat penting. Oleh karena itu, supaya potensi tersebut berkembang dan dapat digunakan dalam peran manusia sebagai wakil Allah di bumi, maka harus ada upaya untuk mengaktualkan potensi tersebut dalam kehidupan sehari-hari. Peran utama konselor dalam bimbingan dan konseling Islami adalah sebagai "Pengingat", sebagai orang yang mengingatkan individu yang dibimbing dengan ajaran agama Islam. Pada dasarnya individu sudah dibekali Allah dengan fitrah iman, jika iman tidak tumbuh, diduga individu tersebut lupa merawatnya, lupa memberi pupuk, atau diserang penyakit, sehingga iman tidak dapat tumbuh dan tidak berfungsi dengan baik. Allah telah mengutus Rasul-Nya dengan Al-Qu'ran sebagai pedoman hidup yang sempurna, jika ada individu yang "kebingungan" dan "salah jalan" dalam menjalani kehidupannya, diduga individu tersebut belum memahami petunjuk yang terdapat dalam Al-Qur'an dan Sunnah Rasul sebagai implementasi Al-Qur'an dalam kehidupan sehari-hari.

Menjadi hakekat dari bimbingan dan konseling Islami adalah sebagai upaya membantu individu belajar mengembangkan fitrah (potensi) manusia dan atau kembali kepada fitrah dengan cara memberdayakan (enpowering) iman, akal, dan kemauan yang dikaruniakan Allah SWT kepadanya untuk mempelajari tuntunan Allah dan Rasul-Nya, agar fitrah yang ada pada individu dapat berkembang dengan benar dan kokoh sesuai tuntunan-Nya. Oleh karena itu, referensi utama yang dijadikan sebagai rujukan dalam bimbingan dan konseling Islami adalah “tuntunan Allah SWT “, yaitu Al-Qur'an dan Sunnah Rasul. Untuk mengembangakan fitrah manusia ada beberapa layanan yang dilakukan yaitu: layanan orientasi agama, layanan imformasi agama, layanan penempatan penyaluran bakat keberagamaan, layanan pengajian agama, layanan konseling agama perorangan dan layanan konseling agama kelompok.

\footnotetext{
${ }^{12}$ Anwar Sutoyo. Bimbingan dan.... Hlm 146
} 


\section{DAFTAR PUSTAKA}

Andi Mapiare. AT. Pengantar Konseling dan Psikoterafi, Jakarta : PT Raja Grafindo Persada, 2002

Anwar Sutoyo, Bimbingan dan Konseling Islami: Teori dan Praktek, Semarang: Widya Karya, 2009

Echols, Jhon. M. dan Hasan Shadily, Kamus Indonesia-Inggris, Jakarta Gramedia, 1994)

Hamka, Tafsir Al-Azhar, Juz I-XXX, Jakarta: Pustaka Panjimas, 1984

Muthaharri, Murthada. Fitrah. Cetakan I, Jakarta: Paramadina, 1989

Shihab, M. Q. Wawasan Al-Quran. Tafsir Maudhu'I Atas Pelbagai Persoalan Umat, Juz I-XV,

Qutub, Sayyid. Tafsir Fi Zilalil Qur'an: Dibawah Naungan Al-Qur'an. Juz I-XI, Jakarta: Gema Insani, 2000

Zakia Drajat, Psikoterafi Islam, Jakarta: Bulan Bintang, 2002 
FITRAH Vol.01 No. 1 Januari-Juni 2015

Aplikasi bayc al-murabahah

Pada bank muamalat cabang padang 